\title{
The putative role of the hormone-sensitive lipase gene in the pathogenesis of Type II diabetes mellitus and abdominal obesity
}

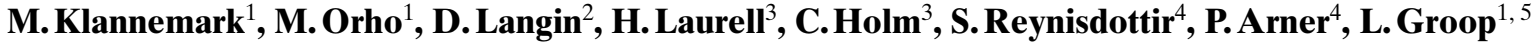 \\ ${ }^{1}$ Department of Endocrinology, Malmö University Hospital, Lund University, Malmö, Sweden \\ ${ }^{2}$ INSERM, Institut Louis Bugnard, Hopital Rangueil, Tolouse, France \\ ${ }^{3}$ Department of Cell and Molecular Biology, Lund University, Lund, Sweden \\ ${ }^{4}$ Huddinge Hospital, Stockholm, Sweden \\ ${ }^{5}$ Department of Medicine, Helsinki University Hospital, Helsinki, Finland
}

Summary Impaired lipolysis has been proposed as a pathogenic factor contributing to clustering of abdominal obesity and dyslipidaemia in Type II (noninsulin-dependent) diabetes mellitus - that is, the metabolic syndrome (MSDR). As this syndrome clusters in families, alterations in the hormone-sensitive lipase (HSL) gene could contribute to the genetic predisposition to MSDR. To test this hypothesis we carried out population and intrafamily association studies in individuals with MSDR, using a polymorphic marker (LIPE) in the HSL gene. There was a significant difference in allele frequency distribution between 235 Type II diabetic patients and 146 control subjects $(p=0.002)$, particularly between 78 abdominally obese Type II diabetic patients with MSDR and the control group $(p=0.010)$. An extended transmission disequilibrium test (TDT) showed transmission disequilibrium of 66 alleles to 42 nondiabetic, abdominally obese offspring in families with Type II diabetes $(p<0.05)$. A slight difference in allele frequency distribution was seen between 71 individuals from the lowest and 71 from the highest tertile of isoprenaline-induced lipolysis in fat tissue $(p=0.07)$. No missense mutations were found with single-strand conformational polymorphism (SSCP) in 20 abdominally obese subjects with MSDR. In conclusion, our population and intrafamily association studies suggest that the LIPE marker in the HSL gene is in linkage disequilibrium with an allele and/or gene which increases susceptibility to abdominal obesity and thereby possibly to Type II diabetes. [Diabetologia (1998) 41: 1516-1522]

Keywords Hormone-sensitive lipase, metabolic syndrome, insulin resistance syndrome, syndrome $\mathrm{X}$, LIPE, dyslipidaemia, Type II (non-insulin-dependent) diabetes mellitus, abdominal obesity.

\section{Received: 22 December 1997 and in revised form: 8 July 1998}

Corresponding author: Professor Leif Groop, Wallenberg Laboratory, Endocrinology and Diabetes, floor 3, UMAS entrance 46, 20502 Malmö, Sweden

Abbreviations: cAMP, cyclic adenosine monophosphate; NEFA, non-esterified fatty acids; HOMA, homeostasis model assessment; HSL, hormone-sensitive lipase; IGT, impaired glucose tolerance; MSDR, metabolic syndrome; NGT, normal glucose tolerance; DMSO, dimethylsulphoxide; PCR, polymerase chain reaction; SSCP, single-strand conformational polymorphism; Tg, plasma triglycerides; WHR, waist-to-hip ratio; WHO, World Health Organisation; TDT, transmission disequilibrium test; D.f., degrees of freedom; RFLP, restriction fragment length polymorphism.
Abdominal obesity, hypertension and dyslipidaemia are strongly associated with Type II (non-insulin-dependent) diabetes mellitus [1,2], and this cluster is often referred to as the metabolic syndrome (MSDR), also called insulin resistance syndrome or Syndrome $X$. According to a preliminary definition by the World Health Organisation (WHO) [3], diabetic patients, patients with impaired glucose tolerance (IGT) and/or insulin resistance have MSDR if they present at least two of the following features: abdominal obesity, increased plasma triglyceride concentrations, reduced HDL cholesterol concentrations, hypertension and/or microalbuminuria. MSDR is associated with an increased risk of atherosclerosis and macrovascular disease $[4,5]$ and is considered to have a strong genetic background [6,7]. In support 
Table 1. Clinical characteristics of the subjects analysed in the association study of the HSL gene and characteristics of MSDR

\begin{tabular}{|c|c|c|c|c|}
\hline & \multicolumn{2}{|l|}{ NGT } & \multicolumn{2}{|c|}{ Type II diabetic } \\
\hline & control subjects & MSDR & nonobese & MSDR \\
\hline$n$ & 146 & 37 & 157 & 78 \\
\hline Sex (males/females) & $71 / 75$ & $26 / 11$ & $81 / 76$ & $34 / 44$ \\
\hline Age at visit (years) & $58.5 \pm 11.9$ & $57.7 \pm 12.1$ & $62.6 \pm 9.4^{\mathrm{a}}$ & $62.2 \pm 8.5^{\mathrm{a}, \mathrm{c}}$ \\
\hline Age at onset of diabetes (years) & - & - & $52.4 \pm 9.3$ & $54.5 \pm 7.2$ \\
\hline BMI $\left(\mathrm{kg} / \mathrm{m}^{2}\right)$ & $24.5 \pm 3.3$ & $29.4 \pm 3.2^{\mathrm{b}}$ & $24.9 \pm 3.0$ & $31.1 \pm 5.0^{\mathrm{b}, \mathrm{f}}$ \\
\hline WHR; men & $0.93 \pm 0.05$ & $1.03 \pm 0.04^{\mathrm{b}}$ & $0.92 \pm 0.04$ & $1.04 \pm 0.04^{b, f}$ \\
\hline WHR; women & $0.80 \pm 0.05$ & $0.93 \pm 0.03^{\mathrm{a}}$ & $0.83 \pm 0.04^{\mathrm{a}}$ & $0.95 \pm 0.04^{\mathrm{b}, \mathrm{c}, \mathrm{f}}$ \\
\hline Triglycerides (mmol/l) & $1.2 \pm 0.4$ & $2.1 \pm 1.1^{\mathrm{a}}$ & $1.3 \pm 0.5$ & $3.0 \pm 0.9^{\mathrm{b}, \mathrm{c}, \mathrm{f}}$ \\
\hline Cholesterol (mmol/l) & $6.0 \pm 1.2$ & $5.7 \pm 1.3$ & $5.9 \pm 1.1$ & $6.2 \pm 1.2^{\mathrm{e}}$ \\
\hline HDL cholesterol (mmol/l); men & $1.38 \pm 0.26$ & $0.84 \pm 0.14^{\mathrm{b}}$ & $1.37 \pm 0.22$ & $0.88 \pm 0.12^{\mathrm{b}, \mathrm{f}}$ \\
\hline HDL cholesterol (mmol/l); women & $1.71 \pm 0.35$ & $0.93 \pm 0.14^{\mathrm{a}}$ & $1.59 \pm 0.33^{\mathrm{a}}$ & $0.92 \pm 0.12^{\mathrm{b}, \mathrm{f}}$ \\
\hline NEFA $(\mu \mathrm{M})$ & $850 \pm 246$ & - & $911 \pm 384$ & $1026 \pm 427$ \\
\hline Systolic blood pressure (mm Hg) & $134 \pm 18$ & $131 \pm 16$ & $144 \pm 19^{\mathrm{a}}$ & $147 \pm 20^{\mathrm{a}, \mathrm{c}}$ \\
\hline Diastolic blood pressure ( $\mathrm{mm} \mathrm{Hg}$ ) & $79 \pm 9$ & $78 \pm 12$ & $79 \pm 9$ & $84 \pm 10^{\mathrm{a}, \mathrm{c}, \mathrm{e}}$ \\
\hline Fasting blood glucose $(\mathrm{mmol} / \mathrm{l})$ & $4.9 \pm 0.5$ & $5.3 \pm 0.7^{\mathrm{a}}$ & $8.8 \pm 3.3^{\mathrm{b}}$ & $9.4 \pm 2.8^{\mathrm{b}, \mathrm{d}}$ \\
\hline $\mathrm{HbA}_{1 \mathrm{c}}(\%)$ & $5.3 \pm 0.5$ & $5.3 \pm 0.5$ & $7.6 \pm 1.8^{\mathrm{b}}$ & $7.7 \pm 1.6^{\mathrm{b}, \mathrm{d}}$ \\
\hline Fasting serum insulin $(\mathrm{nmol} / \mathrm{l})$ & $6.8 \pm 3.3$ & $12.6 \pm 9.5^{\mathrm{a}}$ & $12.9 \pm 16.8^{\mathrm{a}}$ & $19.3 \pm 13.9^{\mathrm{b}, \mathrm{c}, \mathrm{e}}$ \\
\hline HOMA-index for insulin resistance & $1.7 \pm 0.9$ & $3.6 \pm 2.1^{\mathrm{a}}$ & $5.5 \pm 6.7^{\mathrm{b}}$ & $9.0 \pm 9.0^{\mathrm{b}, \mathrm{c}, \mathrm{e}}$ \\
\hline Fasting C-peptide (nmol/l) & $0.34 \pm 0.16$ & $0.59 \pm 0.32^{\mathrm{a}}$ & $0.40 \pm 0.26$ & $0.70 \pm 0.33^{\mathrm{b}, \mathrm{e}}$ \\
\hline \multicolumn{2}{|c|}{$\begin{array}{l}\text { Data are mean } \pm \text { SD. NEFA was measured for } 22 \text { of the } \\
\text { healthy control subjects, } 64 \text { of the nonobese Type II diabetic } \\
\text { patients and } 28 \text { of the MSDR/Type II diabetic patients. No } \\
\text { data on NEFA was available for MSDR/NGT patients. }\end{array}$} & \multicolumn{3}{|c|}{$\begin{array}{l}{ }^{\mathrm{a}} p<0.05,{ }^{\mathrm{b}} p<1 \times 10^{-9} \text { vs control subjects; }{ }^{\mathrm{c}} p<0.05,{ }^{\mathrm{d}} p<1 \times \\
10^{-9} \text { vs MSDR/NGT and }{ }^{\mathrm{e}} p<0.05,{ }^{\mathrm{f}} p<1 \times 10^{-9} \text { vs nonobese } \\
\text { Type II diabetic patients }\end{array}$} \\
\hline
\end{tabular}

of this, MSDR clusters in families and healthy firstdegree relatives of Type II diabetic patients have increased frequency of abdominal obesity, insulin resistance and dyslipidaemia [8]. In addition, many of them have a decreased metabolic rate [8]. Abdominal obesity in association with the characteristic dyslipidaemia and low basal metabolic rate points at disturbances in abdominal fat lipolysis.

Hormone-sensitive lipase (HSL) is the rate-limiting enzyme in the breakdown of triglycerides in adipose tissues. The enzyme is activated by catecholamines through cAMP-dependent phosphorylation, whereas insulin prevents this phosphorylation through increased hydrolysis of cAMP [9-11]. Lipolysis and lipid metabolism are disturbed in patients with Type II diabetes [12], MSDR [13, 14] and in subjects of normal weight with a family history of diabetes [15]. Therefore, genetic variants of the HSL gene could be related to abnormal lipid metabolism, abdominal obesity or Type II diabetes.

The HSL gene is located on chromosome 19q13.113.2 [16]. The adipocyte isoform of HSL is encoded by 9 exons [17]. Adipocyte HSL is composed of two major domains of which the $\mathrm{N}$-terminal domain is largely encoded by exons $1-4$ and the C-terminal catalytic domain by exons 5-9 [18].

To study whether alterations in the HSL gene contribute to the development of MSDR, we carried out association studies and an extended transmission disequilibrium test (ETDT) using a polymorphism in the HSL gene and screened the coding regions of the gene for mutations in diabetic and nondiabetic ab- dominally obese subjects with MSDR. As an additional functional marker for HSL catalytic capacity we used the in vitro maximum lipolytic rate of subcutaneous adipose cells $[13,14]$.

\section{Subjects and methods}

The study consisted of four parts. In the three first studies we analysed association and transmission disequilibrium between a polymorphism in the HSL gene (LIPE) and MSDR or a low lipolytic rate. In the fourth study we carried out mutation screening of the HSL gene in abdominally obese subjects with MSDR.

Subjects and study design. MSDR was defined by waist-to-hip ratio (WHR) $>1.0$ (men) or $>0.9$ (women) and HDL $<1.0 \mathrm{mmol} / \mathrm{l}$ (men) or $<1.1 \mathrm{mmol} / \mathrm{l}$ (women).

1) In the association study with MSDR as the phenotype, 78 Type II diabetic patients with abdominal obesity and low HDL cholesterol concentrations (MSDR/Type II diabetes), 157 nonobese Type II diabetic patients with normal HDL (nonobese Type II diabetes), and 37 abdominally obese subjects with normal glucose tolerance (NGT) and low HDL cholesterol concentrations (MSDR/NGT) were compared with 146 unrelated nonobese, healthy control spouses with NGT and normal HDL cholesterol concentrations and without family history of diabetes. Clinical characteristics of the three study groups are shown in Table 1 . There was a family history of Type II diabetes in 27 of the 37 MSDR/NGT subjects. All subjects were unrelated and selected from the Botnia region in western Finland or from southern Sweden. All groups were matched for ethnicity and statistical tests were done to assure that allele frequencies did not differ between the different subgroups from the two regions. 
Table 2. Clinical characteristics of the subjects analysed in the association study of the HSL gene and lipolytic activity in subcutaneous adipose tissue

\begin{tabular}{|c|c|c|}
\hline & $\begin{array}{l}\text { High lipolytic } \\
\text { activity }\end{array}$ & $\begin{array}{l}\text { Low lipolytic } \\
\text { activity }\end{array}$ \\
\hline$n$ & 71 & 71 \\
\hline Sex (males/females) & $27 / 44$ & $23 / 48$ \\
\hline Age at visit (years) & $38.9 \pm 11.5$ & $41.1 \pm 13.0$ \\
\hline $\mathrm{BMI}\left(\mathrm{kg} / \mathrm{m}^{2}\right)$ & $31.5 \pm 10.5$ & $33.7 \pm 8.6^{\mathrm{a}}$ \\
\hline WHR & $0.93 \pm 0.08$ & $0.95 \pm 0.07^{\mathrm{a}}$ \\
\hline Triglycerides (mmol/l) & $1.8 \pm 2.7$ & $2.0 \pm 1.1^{\mathrm{a}}$ \\
\hline HDL cholesterol (mmol/l) & $1.34 \pm 0.37$ & $1.20 \pm 0.36^{\mathrm{a}}$ \\
\hline Fasting blood glucose $(\mathrm{mmol} / \mathrm{l})$ & $5.4 \pm 1.2$ & $5.5 \pm 1.2$ \\
\hline Fasting plasma insulin (mU/l) & $13.8 \pm 12.4$ & $13.8 \pm 8.2$ \\
\hline Cell volume (pl) & $634 \pm 252$ & $689 \pm 183$ \\
\hline $\begin{array}{l}\text { Basal lipolysis } \\
\left(\mu \mathrm{mol} / 10^{7} \text { cells } / 2 \mathrm{~h}\right)\end{array}$ & $1.79 \pm 0.92$ & $0.96 \pm 0.52^{\mathrm{b}}$ \\
\hline $\begin{array}{l}\text { Isoprenaline-stimulated } \\
\text { lipolysis }\left(\mu \mathrm{mol} / 10^{7} \text { cells } / 2 \mathrm{~h}\right)\end{array}$ & $8.67 \pm 4.58$ & $3.36 \pm 1.06^{\mathrm{c}}$ \\
\hline
\end{tabular}

Data are mean \pm SD. BMI in these groups ranged from $19.7-60.2 \mathrm{~kg} / \mathrm{m}^{2}$ (median $26.1 \mathrm{~kg} / \mathrm{m}^{2}$ ) in the group with high lipolytic rate, and from $20.5-52.6 \mathrm{~kg} / \mathrm{m}^{2}$ (median $31.8 \mathrm{~kg} / \mathrm{m}^{2}$ ) in the group with low lipolytic rate.

${ }^{\mathrm{a}} p<0.05,{ }^{\mathrm{b}} p<1 \times 10^{-8},{ }^{\mathrm{c}} p<1 \times 10^{-23}$ vs subjects with high lipolytic activity

2) In the extended transmission disequilibrium test, 42 unrelated subjects ( 23 men, 19 women) with both parents available for genetic analysis, were selected. Offspring were considered to have MSDR if their WHR exceeded the cut-off level for the highest WHR-quartile of a control group $(n=405$, WHR $\geq 0.967$ for men and $\geq 0.861$ for women). All included offspring had NGT and a first-degree relative with Type II diabetes. Their age was $37.0 \pm 9.3$ years, WHR $1.01 \pm 0.07$ in men and $0.91 \pm 0.07$ in women, BMI $27.2 \pm 4.6 \mathrm{~kg} / \mathrm{m}^{2}$, plasma triglycerides $1.5 \pm 1.0 \mathrm{mmol} / \mathrm{l}$, HDL $1.28 \pm 0.33 \mathrm{mmol} / \mathrm{l}$ in men and $1.42 \pm 0.35 \mathrm{mmol} / \mathrm{l}$ in women, while their homeostasis model assessment (HOMA)-index [19] for insulin resistance was $2.5 \pm 2.1$. Control allele frequencies were determined in 162 unrelated spouses with NGT, lipid metabolism and body constitution, and without family history of diabetes.

3) In the association study with lipolytic rate as the phenotype, 214 unrelated subjects from Sweden with a wide range of BMI $\left(18-60 \mathrm{~kg} / \mathrm{m}^{2}\right)$ were divided into tertiles of isoprenaline-stimulated lipolytic rate in abdominal subcutaneous adipose tissue, after correction for age and mean volume of subcutaneous fatcells $[13,14]$. For the analysis of allele frequency distribution, 71 subjects from the highest tertile were compared with 71 subjects from the lowest tertile (Table 2).

4) For mutation screening, 50 subjects with MSDR were chosen from the abdominally obese patients included in the association study. Of them, 20 subjects ( 11 men and 9 women, 17 Type II diabetic and 1 IGT, age $55.5 \pm 14.2$ years, WHR $1.00 \pm 0.08$, HDL $0.85 \pm 0.23 \mathrm{mmol} / \mathrm{l})$ were screened for all exons and the remaining 30 subjects $(19$ men and 11 women, 18 Type II diabetic and 9 IGT, age $58.0 \pm 13.2$ years, WHR $0.99 \pm 0.07$, HDL $0.92 \pm 0.18 \mathrm{mmol} / \mathrm{l}$ ) for exons 4,6 and 8 . In addition, 39 hypertriglyceridaemic subjects (23 men and 16 women, 27 Type II diabetic and 3 IGT, age $55.5 \pm$ 14.7 years, plasma triglycerides $6.4 \pm 1.4 \mathrm{mmol} / \mathrm{l}$, WHR $0.89 \pm$ $0.06)$ were screened for mutations, of whom 10 were screened for all exons and 29 for exons 4, 6 and 8 .
Clinical investigations and laboratory assays. Waist circumference was measured with a soft tape on standing subjects midway between the lowest rib and the iliac crest and hip circumference over the widest part of the gluteal region [8, 12]. Mean blood pressure values were calculated from three recordings taken from sitting subjects 30 min after rest. Serum total cholesterol, HDL and triglyceride concentrations were measured on a Cobas Mira analyzer (Hoffman LaRoche, Basel, Switzerland). Serum non-esterified fatty acids (NEFA) were measured by microfluorometric assay [20] and serum insulin (Pharmacia, Uppsala, Sweden) and C-peptide [21] concentrations were measured with radioimmunoassay. Type II diabetes and IGT were diagnosed by WHO criteria [22]. The HOMA-index (fasting insulin times fasting plasma glucose divided by 22.5) [22] was used to estimate the degree of insulin resistance (reference value defined as 1.0 for a healthy subject with normal weight and age $<35$ years).

Lipolysis assay. Subcutaneous adipose tissue was obtained by taking biopsies either during local anaesthesia or, for elective surgery, during general anaesthesia. The lipolytic measurements are comparable during both local and general anaesthesia [14]. Isolated adipocytes were prepared and incubated with increasing concentrations $\left(10^{-13}-10^{-6}\right)$ of the non-selective $\beta$ adrenoreceptor agonist isoprenaline as described previously [13]. Glycerol was measured and used as a lipolytic index. Mean fat cell size and weight were determined and the number of adipocytes in each incubation were calculated [13]. The lipolytic rate at the maximum effective agonist concentration was expressed in relation to cell number.

Genotyping. Genomic DNA was extracted from peripheral blood lymphocytes using standard methods [23]. The LIPE marker [16] is a (CA) dinucleotide repeat, located in intron 7 of the human HSL gene and highly polymorphic (heterozygosity index 0.79 ). It was genotyped with radioactive polymerase chain reaction (PCR) using $\gamma$-ATP end-labelled (Amersham Sweden AB, Solna, Sweden) forward primer $\left(5^{\prime}\right.$ CAAAACTGCACCTAATCTTCCC-3' ) and unlabelled reverse primer ( $5^{\prime}$-GTAGGCTGTGTTTCCCCAGACT-3' ${ }^{\prime}$ ). PCR was carried out as earlier described [16] but with the following changes: the reactions were done in a total volume of $15 \mu \mathrm{l}$ with $16 \mathrm{mmol} / \mathrm{l}\left(\mathrm{NH}_{4}\right)_{2} \mathrm{SO}_{4} ; 67 \mathrm{mmol} / \mathrm{l}$ Tris $(\mathrm{pH} \mathrm{8.8)}$; $0.01 \%$ Tween 20; $0.13 \mathrm{mmol} / 1 \mathrm{dNTP} ; 1 \mathrm{mmol} / \mathrm{l} \mathrm{MgCl}_{2} ; 3 \%$ DMSO; $0.2 \mu \mathrm{mol} / 1$ of both primers and $0.5 \mathrm{U}$ Taq polymerase (Perkin Elmer, Foster City, Calif., USA) using 21 ng of genomic DNA as template. The reactions were stopped with $95 \%$ formamide buffer $(1: 1)$, denatured and applied onto a denaturing (5\% urea) $5 \%$ polyacrylamide gel (acrylamide/bisacrylamide $19: 1$ ) and run at $50 \mathrm{~W}$ for $3 \mathrm{~h}$ and $20 \mathrm{~min}$.

Single-strand conformational polymorphism (SSCP). PCR was carried out with intronic primers for amplification of the coding HSL exons and the non-coding exon B located $1.5 \mathrm{~kb}$ upstream of the first coding exon (Table 3) [24]. For exons 1, 8 and 9, overlapping sets of 2 (exons 1 and 9) or 3 (exon 8 ) primers were used, as these exons were too large to be analysed in one fragment. A minimum distance of $25 \mathrm{bp}$ between the intronic primer and exon border was used for all fragments. All the coding exons and the non-coding exon B were screened in 20 abdominally obese subjects with MSDR, and in 10 hypertriglyceridaemic subjects. In addition, 30 abdominally obese subjects with MSDR and 29 hypertriglyceridaemic subjects were screened for exons of putative functional importance: exon 6 encodes the serine of the catalytic triad and exon 8 encodes known phosphorylation sites $[10,18,25]$. In exon 4 , a polymorphism (Arg309Cys) has been identified in a Japanese 
Table 3. Sequences of primer-pairs and variable conditions for PCR-SSCP analysis of the HSL gene

\begin{tabular}{|c|c|c|c|c|}
\hline Primer & Primer sequence & $\begin{array}{l}\text { Fragment } \\
\text { length (bp) }\end{array}$ & $\begin{array}{l}\text { Annealing } \\
\text { temperature }\left({ }^{\circ} \mathrm{C}\right)\end{array}$ & $\begin{array}{l}\text { Enhancer of } \\
\text { PCR-specificity }\end{array}$ \\
\hline $\begin{array}{l}\text { HSL B F } \\
\text { HSL B R }\end{array}$ & $\begin{array}{l}\text { 5'-TCTGTTTACAGCACGTGGTCC-3' } \\
\text { 5'-TGCTCCAGTGACTTCCCTCC-3' }\end{array}$ & 301 & 62 & $1.5 \%$ formamide \\
\hline $\begin{array}{l}\text { HSL 1a F } \\
\text { HSL 1a R }\end{array}$ & $\begin{array}{l}\text { 5'-AACAGGCCTCCCCACCTGCC-3' } \\
\text { 5'-CGGGATTTGTGCAGGAGGTG-3' }\end{array}$ & 314 & 63 & $5 \%$ glycerol \\
\hline $\begin{array}{l}\text { HSL } 1 \mathrm{~b} F \\
\text { HSL } 1 \mathrm{~b} \text { R }\end{array}$ & $\begin{array}{l}\text { 5'-TACCGCAGCCTAGTGCACAC-3' } \\
\text { 5'-GCCTTCATTGTGGGGCCCAG-3' }\end{array}$ & 347 & 63 & $5 \%$ glycerol \\
\hline $\begin{array}{l}\text { HSL } 2 \mathrm{~F} \\
\text { HSL } 2 \mathrm{R}\end{array}$ & $\begin{array}{l}\text { 5'-CATCCCTCTCTTGAGCGGTG-3' } \\
\text { 5'-CCAGTGGGTCAGGCTGCTTG-3' }\end{array}$ & 217 & 63 & $1.5 \%$ formamide \\
\hline $\begin{array}{l}\text { HSL } 3 \text { F } \\
\text { HSL } 3 \text { R }\end{array}$ & $\begin{array}{l}\text { 5'-CAAGCAGCCTGACCCACTGG-3' } \\
\text { 5'-CCTCAGATGATGCTCTGGGC-3' }\end{array}$ & 246 & 63 & $3 \%$ DMSO \\
\hline $\begin{array}{l}\text { HSL } 4 \text { F } \\
\text { HSL } 4 \text { R }\end{array}$ & $\begin{array}{l}\text { 5'-ACCCCTGCAGGCAGACCTTC-3' } \\
5^{\prime} \text {-CCACGCTCCTCGGCTCTGTC-3' }\end{array}$ & 285 & 64 & $1.5 \%$ formamide \\
\hline $\begin{array}{l}\text { HSL } 5 \mathrm{~F} \\
\text { HSL } 5 \mathrm{R}\end{array}$ & 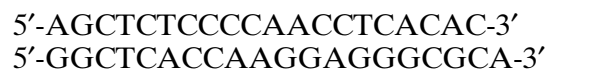 & 348 & 63 & $1.5 \%$ formamide \\
\hline $\begin{array}{l}\text { HSL } 6 \mathrm{~F} \\
\text { HSL } 6 \mathrm{R}\end{array}$ & $\begin{array}{l}\text { 5'-TCTGCCCCTGCCAGGTTGTC-3' } \\
5^{\prime} \text {-GCAGGAGTCAGACATCCATGCA-3' }\end{array}$ & 328 & 65 & $1.5 \%$ formamide \\
\hline $\begin{array}{l}\text { HSL } 7 \text { F } \\
\text { HSL } 7 \text { R }\end{array}$ & $\begin{array}{l}\text { 5'-GGAAAACAACTCAGCTACCCAC-3' } \\
5^{\prime} \text {-AGGCTGTCCCTCCTGCCCAC-3' }\end{array}$ & 267 & 65 & $1.5 \%$ formamide \\
\hline $\begin{array}{l}\text { HSL 8a F } \\
\text { HSL 8a R }\end{array}$ & $\begin{array}{l}\text { 5'-ACCAAACTAACGGAGCCAGG-3' } \\
5^{\prime} \text {-CAGCTCATTTTTGGCCTCAG-3' }\end{array}$ & 285 & 58 & $1.5 \%$ formamide \\
\hline $\begin{array}{l}\text { HSL } 8 b \text { F } \\
\text { HSL } 8 b \text { R }\end{array}$ & 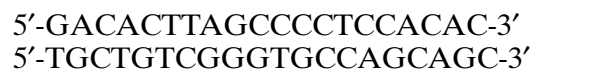 & 239 & 62 & $1.5 \%$ formamide \\
\hline $\begin{array}{l}\text { HSL } 8 \mathrm{c} \mathrm{F} \\
\text { HSL 8c R }\end{array}$ & $\begin{array}{l}\text { 5'-AGAGGCCTGGGCGTCCGTGC-3' } \\
\text { 5'-AGGTGTACCGTGCCCGGTCC-3' }\end{array}$ & 256 & 66 & $3 \%$ DMSO \\
\hline $\begin{array}{l}\text { HSL 9a F } \\
\text { HSL 9a R }\end{array}$ & $\begin{array}{l}5^{\prime} \text {-ACCCTCTCTCCACGTCCCTC-3' } \\
5^{\prime} \text {-ACGAGGCGGATGCGCTCCAC-3' }\end{array}$ & 237 & 64 & $1.5 \%$ formamide \\
\hline $\begin{array}{l}\text { HSL } 9 \mathrm{~b} F \\
\text { HSL } 9 \mathrm{~b} R\end{array}$ & $\begin{array}{l}\text { 5'-CGGCGCTGTGCCGCGAGAC-3' } \\
\text { 5'-TGGCGAGGGTCTCAGCTTTC-3' }^{\prime}\end{array}$ & 283 & 63 & $3 \%$ DMSO \\
\hline
\end{tabular}

The primers HSL BF and HSL BR amplify the 5' non-coding exon of the HSL gene

population [26], and thus 89 subjects were screened seeking to identify subjects with this polymorphism.

PCR was carried out with initial denaturation $\left(96^{\circ} \mathrm{C}\right.$ for $3 \mathrm{~min}$ ) followed by 30 cycles of denaturation $\left(96^{\circ} \mathrm{C}\right.$ for $\left.30 \mathrm{~s}\right)$, annealing ( $30 \mathrm{~s}$, see Table 3 for variable annealing temperatures) and extension $\left(72^{\circ} \mathrm{C}\right.$ for $\left.30 \mathrm{~s}\right)$, followed by final extension $\left(72^{\circ} \mathrm{C}\right.$ for $\left.10 \mathrm{~min}\right)$. The reactions were done in a total volume of $20 \mu \mathrm{l}$ with $16 \mathrm{mmol} / \mathrm{l}\left(\mathrm{NH}_{4}\right)_{2} \mathrm{SO}_{4} ; 67 \mathrm{mmol} / \mathrm{l}$ Tris $(\mathrm{pH}$ 8.8); $0.01 \%$ Tween $20 ; 0.13 \mathrm{mmol} / \mathrm{l} \mathrm{dNTP;} 1.5 \mathrm{mmol} / 1 \mathrm{MgCl}_{2}$; $0.2 \mu \mathrm{mol} / \mathrm{l}$ of both primers; $0.5 \mu \mathrm{Ci} \alpha-{ }^{32} \mathrm{P}-\mathrm{dCTP}$ and $0.5 \mathrm{U}$ Taq polymerase using $21 \mathrm{ng}$ genomic DNA as template. Either $3 \%$ DMSO, $1.5 \%$ formamide or $5 \%$ glycerol (Table 3) was used to increase PCR-sensitivity. The reactions were stopped with $95 \%$ formamide buffer $(1: 1)$, denatured, cooled and electrophoresed on glycerol-free $\left(35 \mathrm{~W}\right.$ for $3.5 \mathrm{~h}$ at $\left.4{ }^{\circ} \mathrm{C}\right)$ and $5 \%$ glycerol ( $8 \mathrm{~W}$ for $12 \mathrm{~h}$ at room temperature), nondenaturing $5 \%$ polyacrylamide gels (acrylamide/bisacrylamide 49:1). When differences in band pattern were observed, PCR-products were sequenced bidirectionally using the ABI PRISM dye terminator cycle sequencing ready reaction kit (Perkin Elmer, Foster City, Calif., USA) and analysed on an automated sequencer (ABI, model 373, Perkin Elmer). Heterozygous variants were confirmed by using the restriction fragment length polymorphism-technique (PCR-RFLP). Using this procedure, the estimated degree of mutation detection is approximately $95 \%$ in our laboratory.

Statistical analysis. Differences in clinical characteristics were tested by Mann-Whitney nonparametric test statistics using the BMDP New System for Windows statistical package (Biomedical Data Processing, Los Angeles, Calif., USA). $P$-values of less than 0.05 were considered statistically significant. Allele frequency distribution was tested by $\chi^{2}$-analysis, and alleles with expected frequencies of less than 5.0 were pooled to assure the validity of the $\chi^{2}$-test. Extended TDT analysis was calculated using the ETDT software package 1.4 for multiallelic markers [27], whereby logistic regression was done to estimate parameters for transmitted and non-transmitted alleles from heterozygous parents. With these parameters, log likelihood was calculated for the allele-wise and genotype-wise model and deviation from the null-hypothesis tested by the McNemar $\chi^{2}$-test.

\section{Results}

Association study of the HSL LIPE marker with $M S D R$ as the phenotype. In these subjects we defined 14 alleles for the HSL LIPE marker (Table 4), ranging in size from 164 to 194 base pairs (bp). The allele frequency distribution of the HSL LIPE marker differed significantly between 235 Type II diabetic patients and 146 healthy control subjects $\left(\chi^{2}=20.6\right.$, 6 degrees of freedom (d.f.), $p=0.002$ ), between $78 \mathrm{MSDR} /$ Type II diabetic patients and the control subjects $\left(\chi^{2}=16.8,6\right.$ d.f., $\left.p=0.010\right)$ and between 157 
Table 4. Distribution of the HSL LIPE alleles in the subjects analysed in the association study of the HSL gene and characteristics of MSDR

\begin{tabular}{|c|c|c|c|c|c|}
\hline \multirow[t]{2}{*}{ Alleles } & \multirow{2}{*}{$\begin{array}{l}\text { Size } \\
\text { (bp) }\end{array}$} & \multicolumn{2}{|l|}{ NGT } & \multicolumn{2}{|c|}{ Type II diabetic } \\
\hline & & $\begin{array}{l}\text { control subjects } \\
n=146\end{array}$ & $\begin{array}{l}\text { MSDR } \\
n=37\end{array}$ & $\begin{array}{l}\text { lean } \\
n=157\end{array}$ & $\begin{array}{l}\text { MSDR } \\
n=78\end{array}$ \\
\hline 1 & 194 & - & - & - & $1(0.6)$ \\
\hline 2 & 192 & $1(0.3)$ & - & $1(0.3)$ & - \\
\hline 3 & 190 & $1(0.3)$ & - & $3(1.0)$ & - \\
\hline 4 & 188 & $10(3.4)$ & $4(5.4)$ & $14(4.5)$ & $9(5.8)$ \\
\hline 5 & 186 & $20(6.8)$ & $8(10.8)$ & $11(3.5)$ & $3(1.9)$ \\
\hline 6 & 184 & $86(29.5)$ & $24(32.4)$ & $95(30.2)$ & $42(26.9)$ \\
\hline 7 & 182 & $97(33.2)$ & $15(20.2)$ & $90(28.7)$ & $45(28.8)$ \\
\hline 8 & 180 & $46(15.7)$ & $12(16.2)$ & $44(14.0)$ & $25(16.0)$ \\
\hline 9 & 178 & $3(1.0)$ & $1(1.3)$ & $9(2.9)$ & $1(0.6)$ \\
\hline 10 & 176 & - & - & $3(1.0)$ & $1(0.6)$ \\
\hline 11 & 174 & - & - & $3(1.0)$ & $1(0.6)$ \\
\hline 12 & 172 & $22(7.5)$ & $5(6.8)$ & $30(9.6)$ & $17(10.9)$ \\
\hline 13 & 170 & $2(0.7)$ & $1(1.3)$ & $2(0.6)$ & $4(2.6)$ \\
\hline 15 & 164 & $4(1.4)$ & $4(5.4)$ & $9(2.9)$ & $7(4.5)$ \\
\hline Total & & $292(100)$ & $74(100)$ & $314(100)$ & $156(100)$ \\
\hline
\end{tabular}

Data are $n(\%)$. Alleles with expected frequencies $<5$ were pooled into one group $(1-3,9-11,13)$ for the $\chi^{2}$-analysis

nonobese Type II diabetic patients and the control subjects $\left(\chi^{2}=15.1,6\right.$ d.f., $\left.p=0.020\right)$. No difference was seen between MSDR/Type II diabetic and nonobese Type II diabetic patients $\left(\chi^{2}=2.2,6\right.$ d.f., $p=$ $0.9)$. No significant difference in allele frequency distribution was observed between $37 \mathrm{MSDR} / \mathrm{NGT}$ and healthy control subjects $\left(\chi^{2}=7.4,5\right.$ d.f. and $p=$ $0.19)$. The combined group of diabetic and nondiabetic individuals with MSDR, however, differed from control subjects $\left(\chi^{2}=15.1,6\right.$ d.f. and $\left.p=0.019\right)$ but not from the pooled group of nonobese Type II diabetic and control subjects $\left(\chi^{2}=6.5,7\right.$ d.f., $p=$ $0.48)$. To exclude ethnic distortion we also carried out the analysis in the Botnia population only. We observed significant differences in allele frequency distribution between all Type II diabetic patients and control subjects $(p=0.007)$, between MSDR/Type II diabetic patients and control subjects $(p=0.010)$ and a smaller difference between nonobese Type II diabetic patients and control subjects $(p=0.06)$.

Extended transmission disequilibrium test (ETDT) in abdominally obese offspring. We genotyped 42 abdominally obese offspring and their parents for the HSL LIPE marker. Of these offspring 39 had a diabetic parent and the remaining three had at least one diabetic sibling. There were eighteen homozygous parents who were thus not informative for transmission of alleles. Transmission was informative for sixty-six parental alleles, and in this set of families eleven different alleles of the HSL LIPE marker were transmitted. Results from both the allele-wise $\left(\chi^{2}=\right.$ 20.0, 10 d.f., $p=0.029)$ and the genotype-wise $\left(\chi^{2}=\right.$ 35.1, 23 d.f., $p=0.052)$ model indicated that certain alleles were preferentially transmitted to abdominally obese offspring in families with Type II diabetes.
Table 5. Distribution of the HSL LIPE alleles in the subjects analysed in the association study of the HSL gene and lipolytic activity in subcutaneous adipose tissue

\begin{tabular}{llcc}
\hline Alleles & $\begin{array}{l}\text { Size } \\
(\mathrm{bp})\end{array}$ & $\begin{array}{l}\text { High lipolysis } \\
n=71\end{array}$ & $\begin{array}{l}\text { Low lipolysis } \\
n=71\end{array}$ \\
\hline 3 & 190 & $1(0.7)$ & $4(2.8)$ \\
4 & 188 & $7(4.9)$ & $2(1.4)$ \\
5 & 186 & $9(6.3)$ & $2(1.4)$ \\
6 & 184 & $43(30.3)$ & $42(29.6)$ \\
7 & 182 & $35(25.6)$ & $55(38.7)$ \\
8 & 180 & $22(15.5)$ & $19(13.3)$ \\
9 & 178 & $2(1.4)$ & $3(2.1)$ \\
10 & 176 & $1(0.7)$ & $2(1.4)$ \\
11 & 174 & $1(0.7)$ & $2(1.4)$ \\
12 & 172 & $11(7.7)$ & $6(4.2)$ \\
13 & 170 & $1(0.7)$ & $2(1.4)$ \\
15 & 164 & $9(6.3)$ & $3(2.1)$ \\
Total & & $142(100)$ & $142(100)$ \\
\hline
\end{tabular}

Data are $n(\%)$. Alleles with expected frequencies $<5$ were pooled into one group $(1-5,9-11,13-15)$ for the $\chi^{2}$-analysis

The result from the two models does not significantly differ $\left(\chi^{2}=15.1,13\right.$ d.f., $\left.p=0.30\right)$. No individual allele explained the transmission disequilibrium, although allele 5 accounted for the greatest deviation from the expected transmission $(p=0.14$, after correction for multiple comparisons).

Association study of the HSL LIPE marker with low lipolytic rate as the phenotype. The difference in allele frequency distribution (Table 5) of the HSL LIPE marker between subjects with high $(n=71)$ and low $(n=71)$ lipolytic activity did not reach statistical significance $\left(\chi^{2}=8.6,4\right.$ d.f., $\left.p=0.072\right)$.

SSCP mutation screening in abdominally obese patients with MSDR. We did not identify any missense 
mutations in the HSL gene in 20 abdominally obese patients with MSDR. In one subject, however, a silent variant was found in codon 756 (exon 9), changing a GCC (alanine) to a GCT (alanine). Furthermore, in another subject we identified a variant changing a $\mathrm{G}$ to $\mathrm{T}$ in nucleotide +41 of the non-coding exon $\mathrm{B}$. These variants were confirmed by PCR-RFLP using restriction enzymes $B c n I$, (for the codon 756 variant) and $M b o I$ (for the position +41 variant). The codon 756 variant was detected in one of 60 subjects screened, and the position +41 variant in one of 30 subjects screened. No additional mutations were identified in the 10 hypertriglyceridaemic subjects screened for all exons. Neither did we detect any mutations in the 30 abdominally obese subjects or in the 29 hypertriglyceridaemic subjects screened for exons 4, 6 and 8. A polymorphism described previously in exon 4 of the HSL gene (Arg309Cys), seen in $5.2 \%$ of Japanese control subjects [26], could not be detected in 89 Scandinavian subjects.

\section{Discussion}

The allele frequency distribution of the HSL LIPE polymorphic marker showed a considerable difference between abdominally obese Type II diabetic patients with low HDL cholesterol and healthy control subjects. This was also true when we compared nonobese Type II diabetic patients without signs of MSDR and healthy control subjects, whereas no noticeable difference was observed between obese and nonobese Type II diabetic patients. Neither was there any important difference in the allele frequency distribution between nondiabetic subjects with features of MSDR and lean control subjects. This was also reported before [28], and it could thus mean that the HSL LIPE polymorphism increases susceptibility to Type II diabetes rather than to abdominal obesity or MSDR. The intrafamily association study, however, could provide some more insight into the phenotype associated with the HSL gene.

The ETDT study clearly showed distorted transmission of alleles to abdominally obese offspring in families with Type II diabetes. As abdominal obesity is a risk factor for Type II diabetes [8], it seems likely that the LIPE marker in the HSL gene is in linkage disequilibrium with a gene increasing susceptibility to abdominal obesity and thereby possibly to Type II diabetes. The positive TDT-result also imply that there is some degree of linkage, suggesting that this locus may be close.

Given the association between the HSL gene and Type II diabetes, an association is also probable with impaired stimulation of lipolysis. Patients with familial combined hyperlipidaemia [14] and nonobese women with polycystic ovary syndrome [29] have markedly impaired catecholamine-induced lipolysis which at least in part is due to impaired function of HSL. When comparing individuals from the lowest with those from the highest tertile of lipolysis we observed a slight difference in allele frequency distribution between the groups $(p=0.07)$. Given the number of alleles at this locus, however, the comparison between these extreme groups detected no noticeable difference. On the other hand, when comparing groups below and above the median of the lipolytic rate there was no difference at all between the groups $(p=0.52)$. It is therefore still possible that a biallelic marker in the HSL gene could show an association with a low lipolytic rate.

The coding regions of the HSL gene and the noncoding exon B were screened for mutations in abdominally obese patients with MSDR using the SSCP technique. Despite the positive association between MSDR and the HSL gene, no missense mutations were identified. A silent mutation ( $\mathrm{Ala}^{756}$ $\mathrm{GCC} \rightarrow \mathrm{GCT}$ ) and a non-coding mutation (exon B, bp $41 \mathrm{G} \rightarrow \mathrm{T}$ ) were found, but the prevalence of these mutations was very low.

Few previous studies have examined the role of the HSL gene in the development of obesity and MSDR. In a Japanese population, a polymorphism has been observed in the coding regions of the HSL gene [26], changing an arginine to a cysteine in codon 309 (exon 4). It was present in $5.2 \%$ of the control population, and there was no difference in the allele frequency between Type II diabetic patients and healthy subjects. Serum triglyceride and HDL-cholesterol concentrations were similar in subjects with either arginine or cysteine in this position, while total serum cholesterol concentration were higher in Type II diabetic subjects heterozygous for Arg309Cys [26]. The polymorphism in codon 309 could not be identified in our study group. In a more recent study, a polymorphic marker in intron 6 of the HSL gene was associated with both obesity and Type II diabetes in a French population [28].

In conclusion, our population and intrafamily association studies suggest that the LIPE marker in the HSL gene is in linkage disequilibrium with an allele and/or gene that increases susceptibility to abdominal obesity and thereby possibly to Type II diabetes.

Acknowledgements. We would like to thank A.Suomalainen and P.Almgren for computational and statistical expertise, and M. Ảberg for technical support. This work was supported by grants from the Sigrid Juselius Foundation, the Albert Påhlsson Foundation, Malmö University Hospital, the Medical Faculty of Lund University, the Swedish Medical Research Council, the Novo Nordisk Foundation, the Swedish Diabetes Foundation, the Juvenile Diabetes Foundation and EEC-grant BMH4-CT95-0662.

Note added in proof: Of the subjects analysed in the association study with MSDR as the phenotype, six of the 78 NIDDM/Type II diabetes patients $(7.7 \%)$ and seven of the 146 controls $(4.8 \%)$ had the $\mathrm{C} \rightarrow \mathrm{T} /$ codon 756 variant 
$(p=0.38)$. Additionally, one patient with MSDR/Type II diabetes carried the $\mathrm{C} \rightarrow \mathrm{T} / \mathrm{exon} \mathrm{B}$ variant, compared to none of the controls.

\section{References}

1. Reaven GM (1988) Role of insulin resistance in human disease. Diabetes 37: 1595-1607

2. Ginsberg HN (1996) Diabetic dyslipidemia: basic mechanisms underlying the common hypertriglyceridemia and low HDL cholesterol levels. Diabetes 45 [Suppl 3]: S27-S30

3. Alberti KGMM, Zimmet PZ, for the WHO Consultation (1998) Definition, diagnosis and classification of diabetes mellitus and its complications. Part 1: Diagnosis and classification of diabetes mellitus. Provisional report of a WHO consultation. Diabetic Medicine 15: 539-553

4. Taskinen MR (1993) Hyperinsulinism and dyslipidemias as coronary heart disease risk factors in NIDDM. Adv Exp Med Biol 334: 295-301

5. Haffner SM, Fong D, Hazuda HP, Pugh JA, Patterson JK (1988) Hyperinsulinemia, upper body adiposity, and cardiovascular risk factors in non-diabetics. Metabolism 37: 338-345

6. Rice T, Després JP, Daw EW et al. (1997) Familial resemblance for abdominal visceral fat: The HERITAGE family study. Int J Obes Relat Metab Disord 21: 1024-1031

7. Newman B, Selby JV, King MC, Slemenda C, Fabsitz R, Friedman GD (1987) Concordance for Type 2 (non-insulin-dependent) diabetes mellitus in male twins. Diabetologia 30: 763-768

8. Groop L, Forsblom C, Lehtovirta M et al. (1996) Metabolic consequences of a family history of NIDDM (The Botnia study). Evidence for sex-specific parental effects. Diabetes 45: 1585-1593

9. Strålfors P, Belfrage P (1983) Phosphorylation of hormonesensitive lipase by cyclic-AMP-dependent protein kinase. J Biol Chem 258: 15146-15152

10. Strålfors P, Björgell P, Belfrage P (1984) Hormonal regulation of hormone-sensitive lipase in intact adipocytes: Identification of phosphorylated sites and effects on the phosphorylation by lipolytic hormones and insulin. Proc Natl Acad Sci USA 81: 3317-3321

11. Degerman E, Leroy M-J, Taira M, Belfrage P, Manganiello $\mathrm{V}$ (1996) A role for the insulin-mediated regulation of cyclic guanosine monophosphate (cGMP) - inhibited phosphodiesterase in the antilipolytic action of insulin. In: Le Roith D, Olefsky JM, and Taylor S (eds.). Diabetes Mellitus: A fundamental and clinical text. Lippincott Co., Philadelphia, p 197

12. Groop LC, Saloranta C, Shank M, Bonadonna RC, Ferrannini E, DeFronzo RA (1991) The role of free fatty acid metabolism in the pathogenesis of insulin resistance in obesity and non-insulin-dependent diabetes mellitus. J Clin Endocrinol Metab 72: 96-107

13. Reynisdottir S, Ellerfeldt R, Wahrenberg H, Lithell H, Arner P (1994) Multiple lipolysis defects in the insulin resistance (metabolic) syndrome. J Clin Invest 93: 2590-2599
14. Reynisdottir S, Eriksson M, Angelin B, Arner P (1995) Impaired activation of adipocyte lipolysis in familial combined hyperlipidemia. J Clin Invest 95: 2161-2169

15. Hellström L, Langin D, Reynisdottir S, Dauzats M, Arner $P$ (1996) Adipocyte lipolysis in normal weight subjects with obesity among first-degree relatives. Diabetologia 39: 921-928

16. Levitt RC, Liu Z, Nourin N, Meyers DA, Brandriff B, Mohrenweiser HM (1995) Mapping of the gene for hormone sensitive lipase (LIPE) to chromosome 19q13.1 $\rightarrow$ q13.2. Cytogenet Cell Genet 69: 211-214

17. Langin D, Laurell H, Holst LS, Belfrage P, Holm C (1993) Gene organisation and primary structure of human hormone-sensitive lipase: possible significance of a sequence homology with a lipase of Moraxella TA 144, an Antarctic bacterium. Proc Natl Acad Sci USA 90: 4897-4901

18. Østerlund T, Danielsson B, Degerman E et al. (1996) Domain structure analysis of recombinant rat hormone-sensitive lipase. Biochem J 319: 411-420

19. Matthews DR, Hosker JP, Rudenski AS, Naylor BA, Treacher DF, Turner RC (1985) Homeostasis model assessment: insulin resistance and $\beta$-cell function from fasting plasma glucose and insulin concentrations in man. Diabetologia 28: 412-419

20. Miles JR, Glassock J, Aikens J, Gerich, Haymond M (1983) A microfluorometric method for the determination of free fatty acids in plasma. J Lipid Res 24: 96-99

21. Heding LG (1975) Radioimmunological determination of human C-peptide in serum. Diabetologia 11: 541-548

22. World Health Organization Study Group on Diabetes Mellitus (1985) Technical report series No 727, WHO, Geneva

23. Vandenplas S, Wiid I, Grobler Rabie A et al. (1984) Blot hybridisation analysis of genomic DNA. J Med Genet 21: 164-172

24. Grober J, Laurell H, Blaise R, Fabry B, Schaak S, Holm C, Langin D (1997) Characterization of the promoter of human adipocyte hormone-sensitive lipase. Biochem J 328: 453-461

25. Contreras JA, Karlsson M, Osterlund T, Laurell H, Svensson A, Holm C (1996) Hormone-sensitive lipase is structurally related to acetylcholinesterase, bile salt-stimulated lipase, and several fungal lipases. Building of a three-dimensional model for the catalytic domain of hormone-sensitive lipase. J Biol Chem 271: 31426-31430

26. Shimada F, Makino H, Hashimoto N et al. (1996) Detection of an amino acid polymorphism in hormone-sensitive lipase in Japanese subjects. Metabolism 45: 862-864

27. Sham PC, Curtis D (1995) An extended transmission/disequilibrium test (TDT) for multi-allele marker loci. Ann Hum Genet 59: 323-336

28. Magre J, Laurell H, Fizames C et al. (1998) Human hormone-sensitive lipase: genetic mapping, identification of a new dinucleotide repeat, and association with obesity and NIDDM. Diabetes 47 (2): 284-286

29. Ek I, Arner P, Bergquist A, Carlström K, Wahrenberg H (1997) Impaired adipocyte lipolysis in nonobese women with polycystic ovary syndrome: A possible link to insulin resistance? J Clin Endocrinol Metab 82: 1147-1153 